\title{
Corrosivity Study of Sensitized Welded and Unwelded Austenitic Stainless Steel AISI 304 in Oxidizing and Non- Oxidizing Environment
}

\author{
Silas Ezedinma Agbokwor, Daniel Oray Nnamdi Obikwelu, Simeon Ikechukwu Neife, Camillus \\ Sunday Obayi
}

\begin{abstract}
An experimental investigation was carried out to determine the corrosive impact of oxidizing and non-oxidizing environments on sensitized welded and unwelded samples of AISI 304. The selected samples were cut into several sizes. To induce sensitization, the samples were heated and soaked at $750^{\circ} \mathrm{C}$ at different soaking time intervals such as 30 minutes, 60 minutes, 180minutes, 300 minutes and 600 minutes followed by water quenching [1]. The resultant sensitized weldment and unwelded samples were subjected to immersion duration test each in oxidizing $\left(\mathrm{H}_{2} \mathrm{SO}_{4}\right)$ and non-oxidizing (HCL) media for $5,10,15,20,25,30,35,40,45, \& 50$ minutes respectively. From the results obtained, it was concluded that corrosion rate decreases as soaking time/immersion duration increases, at constant soaking temperature in non-oxidizing medium of hydrochloric acid (HCL). However, the corrosion rate decrease of the unwelded samples of AISI 304 in non-oxidizing medium is greater than that of their welded counterpart as immersion duration/soaking time increases. Similarly, the unwelded and welded samples of AISI 304, in oxidizing medium of $\mathrm{H}_{2} \mathrm{SO}_{4}$ have one common characteristic with their corrosion rate decreasing as soaking time/immersion duration increases; but, surprisingly, the welded samples are having lower corrosion rate than that of the unwelded counterpart as the immersion duration/soaking time increases between 5-15minutes; but reverses to a higher corrosion rate than their unwelded counterpart as immersion duration increases between 15-50 minutes. The results showed that each sample reacted differently in oxidizing and non-oxidizing media; hence oxidizing and non-oxidizing media impacted the materials' properties differently. The sensitization differences of the welded and the unwelded counterpart obtained during soaking time, significantly affected their reactions in oxidizing and nonoxidizing media which led to differences in the corrosive impacts, under the same environment.
\end{abstract}

Index Terms-Corrosion Rate, Immersion Duration, Oxidizing (HCL) and Non-Oxidizing $\left(\mathrm{H}_{2} \mathrm{SO}_{4}\right)$ Media, Sensitization, Soaking Time/Temperature, Welded/Unwelded AISI 304.

\section{INTRODUCTION}

The most important failure mechanism in present day industries is materials' corrosion [2]. Although polymers and composites were introduced for improved qualities;

Published on October 31, 2019

S. E. Agbokwor is with the Department of Mechanical Engineering, Faculty of Engineering, University of Nigeria Nsukka, Nsukka, Nigeria. (Corresponding author, e-mail: chideraogo@yahoo.com, agbokwor.silas@nnecltd.com)

D. O. N. Obikwelu, S. I. Neife, C. S. Obayi are with the Department of Metallurgical and Materials Engineering, Faculty of Engineering University of Nigeria Nsukka, Nsukka, Nigeria. stainless steels still remain very important in structures; because of their strength, stiffness, toughness and tolerance at high temperatures [3]. They are widely used in harsh oil and gas production environments; for instance, they are found at Catalytic Reformer Unit, Reactor Scallops, Vacuum Distillation Unit and Heat Tubes at Port Harcourt Refinery-Nigeria; process and utility areas of Mobil producing Nigeria unlimited and Chevron Escravos gas to liquid plants also in Nigeria [1]. Austenitic stainless steel (ASS) is widely used in caustic environments [4-8].

It is a known fact that corrosion resistance is the main reasons why stainless steels are used in our industries today; but unfortunately, they suffer from certain types of corrosion in some environments. These facilities structures usually in welded form in order to achieve the desired design, have been observed to experience various debilitating forms of localized corrosion like pitting, crevice and stress corrosion cracking [9-14], when exposed to chloride containing solution environments; leading to loss of millions of dollars each year [16-17]. Austenitic Stainless Steel is sensitivity to chloride-induced stress-corrosion cracking (SCC) [18-19].

The failure of the passive film is as a result of their micro structural changes at the grain boundaries, complicated by environmental factors [20-22]. Environment characterized by high temperature for instance; can cause some precipitation of second phase carbides of various sizes in the microstructure of the stainless steels. Oxidation and nonoxidation media can result in complex reactions with undesirable second phase products and consequent decrease in corrosion resistance. Time, temperature/other environment factors significantly influences unusual complex/sensitized microstructure of steels and hence its properties [23-25]. Care therefore, must be taken for material selection which would be suitable for certain application in a given environment.

The harsh acidic environment at the sensitized regions can be too aggressive to allow passivity to be maintained by; being too reducing, in some acidic media (e.g. Hydrochloric acid); so that passivating species cannot form or by being too oxidizing (e.g. Hot dilute nitric acid or $\mathrm{H}_{2} \mathrm{SO}_{4}$ ) by making oxidized species that normally affect passivity unstable. Weld decay has been observed to be common in sensitized stainless steel structures [26].

It is a known fact that these unavoidable circumstances of corrosion could result in a metal with a dendritic and inhomogeneous microstructure. Steels naturally have many micro structural complexities with many constituent elements and many thermodynamically possible phases. 
Interestingly, none of these phases/structures are necessarily uniform in their composition; yet, it is the composition of the alloy in contact with the specific environment at any microscopic point that determines the corrosion resistance of that particular point [1]. It is therefore not unusual to find out that some alloy of a metal is resistant to corrosion in a particular environment, but the welded section of the same alloy is not. Welds sometimes may behave in an erratic manner; displaying both resistance and susceptibility to corrosive attack.

The disastrous consequences of weld decay are worrisome and equally disturbing because of uncountable cases despite numerous researches. This research was therefore; set out to carry out an experimental study of the influence of environments on the corrosivity of sensitized welded and unwelded stainless steels (AISI 304). The inferences from the experimental results would assist;

To establish relationship as observed from the experiments on the various factors (oxidizing and nonoxidizing environment, alloy composition, microstructure, Temperature, Soaking Time/immersion duration, etc), that may have significant influence on the corrosivity of the steel. These understanding would assist in mitigating the menace as low as reasonably practicable, in a given susceptible environment.

\section{Methodology}

\section{A. Materials}

AISI 304 austenitic stainless steel was selected for this investigation, because of its commercial value. The sample is a commercial pure sample and was available in the form of pipes and was collected from the ware house of Port Harcourt Refinery Company Ltd, Alese Eleme, Port Harcourt, Rivers State-Nigeria

\section{B. Equipment}

Equipment used for the study are as follows: Welding machines, Grinding Machines, Cutting Machines, Universal milling machine, Manual hand Hacksaw with blade, heat treatment furnace, Oxford instrument XRF spectrometer model X-Met 7000 with a serial number 711150, Crown technology inc. CT 1000 corrosion meter (capable of reading corrosion rate), Epoxy Resin Ring, Emery Paper.

\section{Experimentation}

\section{1) Chemical Composition}

The chemical composition of the welded and unwelded samples of AISI 304 were determined at Turret Engineering Services Limited, Port Harcourt using an Oxford instrument XRF spectrometer model X-Met 7000 with serial number 711150. The chemical composition details of the samples are as shown Fig. 1 and Fig. 2 below.

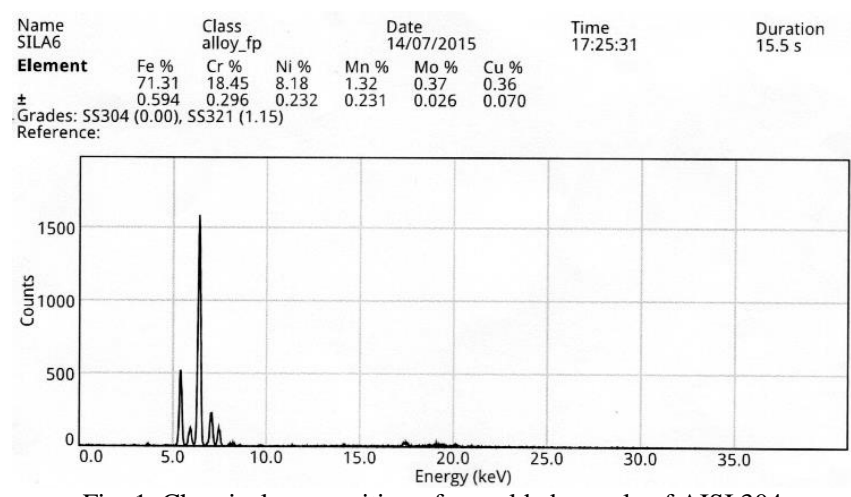

Fig. 1. Chemical composition of unwelded sample of AISI 304

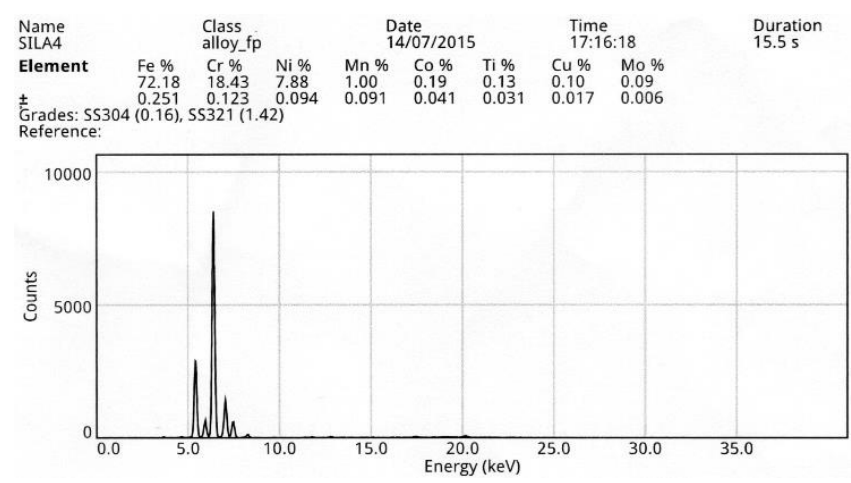

Fig. 2. Chemical composition of welded sample of AISI 304

2) Heat Treatment

The welded samples which met all necessary welding requirements (GPs, Codes and Standards) and the unwelded samples were cut to sizes and subjected to heat treatment using solution annealing to dissolve precipitated phases, if any. The treatment was carried out for 1 hour at $1000^{\circ} \mathrm{C}$, followed by water quenching.

The welded and the unwelded samples were then cut into several equal pieces; properly numbered for easy identification. To induce sensitization into the samples; they were heated and soaked at $750^{\circ} \mathrm{C}$ for different time intervals such as 30 minutes, 60 minutes, 180minutes, 300 minutes, 500 minutes, 400 minutes and 600minutes followed by water quenching. This type of heat treatment schedule was done by varying the holding times suggested in Ghosh et al.

Corrosion study was therefore carried out on the sensitized welded and unwelded samples of AISI 304 steels; by immersion of the treated samples each at different time intervals of $5,10,15,20,25,30,35,40,45$, and 50 minutes, respectively; in non-oxidizing (HCL) and oxidizing ( $\mathrm{H}_{2} \mathrm{SO}_{4}$ ) corrosive media. The tabulated results/ graphical representations and analysis, are as shown below.

\section{RESUlTS AND DISCUSSIONS}

\section{A. Table I and Fig. 3}

From Table I and Fig. 3 below; sample 4A has the highest corrosion rate $(18.45 \mathrm{mpy})$ at five minutes of immersion duration in the non-oxidizing medium of hydrochloric acid (HCL); but decreased sharply to $2.72 \mathrm{mpy}$ as immersion duration increased to 15 minutes; then fluctuates downwards as immersion duration increases. Corrosion rate of $4 \mathrm{~A}, 5 \mathrm{~A}$, 6A, 7A, have initial sharp decreases; but fluctuates gradually downwards at lower corrosion rate as immersion 
duration increases. 5A has the lowest corrosion rate at 30minutes immersion duration.

Careful study showed that corrosion rate of $1 \mathrm{~A}, 2 \mathrm{~A}$ and $3 \mathrm{~A}$ are more stable and at a lower corrosion rates, as immersion duration/soaking time increases in HCL. However; in all the samples, the resistance to corrosion tend to increase as immersion duration and soaking time increases at constant soaking temperature.

TABLE I: CORROSION RATE(COR) OF UNWELDED AISI 304 SAMPLES ( $1 \mathrm{~A}$, $2 \mathrm{~A}, 3 \mathrm{~A}, 4 \mathrm{~A}, 5 \mathrm{~A}, 6 \mathrm{~A}, 7 \mathrm{~A})$, SOAKED AT $750^{\circ} \mathrm{C}$ AT VARIABLE SOAKING TIME OF $30,60,180,300,400,500$ AND 600 MINUTES RESPECTIVELY AND IMMERSED IN NON-OXIDIZING AGENT (HCL) AT VARIABLE IMMERSION

\begin{tabular}{|c|c|c|c|c|c|c|c|}
\hline \multicolumn{8}{|c|}{ DURATION } \\
\hline Immersion & $1 \mathrm{~A}$ & $2 \mathrm{~A}$ & $3 \mathrm{~A}$ & $4 \mathrm{~A}$ & $5 \mathrm{~A}$ & $6 \mathrm{~A}$ & $7 \mathrm{~A}$ \\
\hline $\begin{array}{c}\text { duration } \\
\text { (Minutes) }\end{array}$ & $\begin{array}{c}\mathrm{COR} \\
(\mathrm{mpy})\end{array}$ & $\begin{array}{c}\text { COR } \\
(\mathrm{mpy})\end{array}$ & $\begin{array}{l}\mathrm{COR} \\
(\mathrm{mpy})\end{array}$ & $\begin{array}{l}\text { COR } \\
\text { (mpy) }\end{array}$ & $\begin{array}{l}\text { COR } \\
\text { (mpy) }\end{array}$ & $\begin{array}{l}\text { COR } \\
\text { (mpy) }\end{array}$ & $\begin{array}{l}\text { COR } \\
\text { (mpy) }\end{array}$ \\
\hline 5 & 4.20 & 3.93 & 3.50 & 18.45 & 10.50 & 7.94 & 7.92 \\
\hline 10 & 3.50 & 3.70 & 3.47 & 8.90 & 7.18 & 7.05 & 3.71 \\
\hline 15 & 4.80 & 2.96 & 2.76 & 2.82 & 3.65 & 3.26 & 3.55 \\
\hline 20 & 3.53 & 3.01 & 3.00 & 4.14 & 3.60 & 3.29 & 3.77 \\
\hline 25 & 3.28 & 3.19 & 3.42 & 3.33 & 3.43 & 3.24 & 3.34 \\
\hline 30 & 3.07 & 2.92 & 3.30 & 4.70 & 1.58 & 4.48 & 3.65 \\
\hline 35 & 3.02 & 2.83 & 3.07 & 3.64 & 3.98 & 2.43 & 2.59 \\
\hline 40 & 2.58 & 2.81 & 3.16 & 3.00 & 2.49 & 2.87 & 2.30 \\
\hline 45 & 2.40 & 2.33 & 2.84 & 2.75 & 2.87 & 3.54 & 3.91 \\
\hline 50 & 2.19 & 2.76 & 2.96 & 3.38 & 2.73 & 2.30 & 2.44 \\
\hline
\end{tabular}

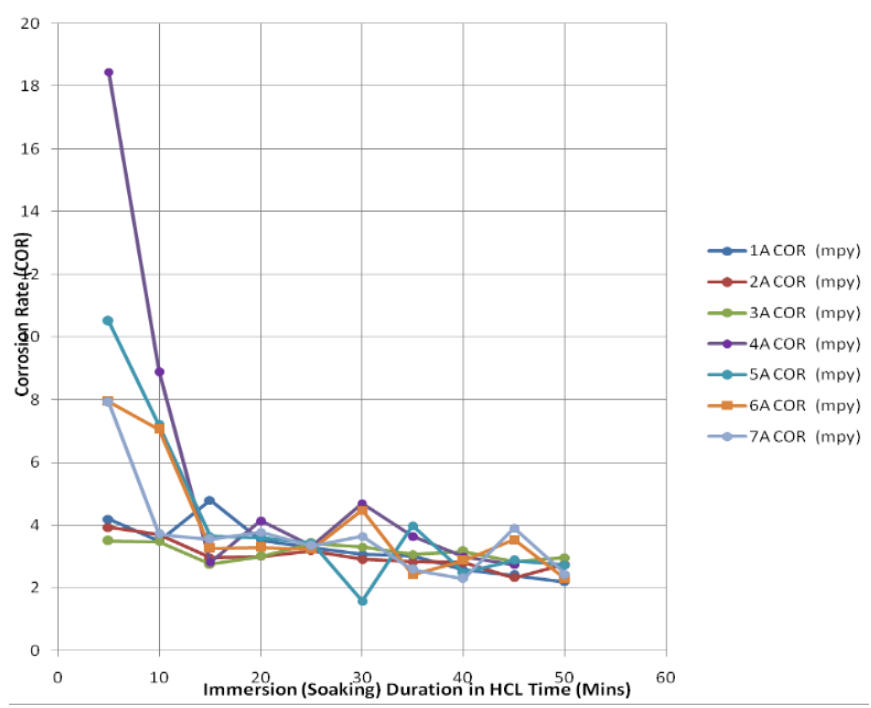

Fig. 3. Graphical representation of Table I (Immersion duration in nonoxidizing medium (HCL) versus corrosion rate (COR)

\section{B. Table II and Fig. 4}

From Table II and Fig. 4 below, sample $2 \mathrm{AW}$ has the highest corrosion rate $(16.57 \mathrm{mpy})$ within five minutes of immersion duration in the non-oxidizing medium of hydrochloric acid (HCL); but decreased sharply (9.65mpy) as immersion duration increases up to 10 minutes; then gradually decreases as immersion duration increases.

Careful study of the Table II and Fig. 4 below showed that sample 7A fluctuates unusually at lower corrosion rate between 20 and 30 minutes of immersion duration; decreasing and increasing sharply at lower corrosion rates. In all the immersion durations, corrosion rates of samples $4 \mathrm{~A}, 5 \mathrm{~A}, 6 \mathrm{~A}, 7 \mathrm{~A}$ are smaller than that of $1 \mathrm{~A}, 2 \mathrm{~A}$ and $3 \mathrm{~A}$. Characteristically from the table and the graph, corrosion rates of all the samples tend to decrease as immersion duration/soaking time increases in the non-oxidizing medium.
TABLE II: CORROSION RATE(COR) OF WELDED AISI 304 SAMPLES (1AW 2AW, 3AW, 4AW, 5AW, 6AW, 7AW), SOAKED AT $750^{\circ} \mathrm{C}$ AT VARIABLE SOAKING TIME OF 30, 60, 180, 300, 400, 500 AND 600 MINUTES RESPECTIVELY AND IMMERSED IN NON-OXIDIZING AGENT (HCL) AT VARIABLE IMMERSION DURATION

\begin{tabular}{cccccccc}
\hline \hline $\begin{array}{c}\text { Immersion } \\
\text { duration } \\
\text { (Minutes) }\end{array}$ & \begin{tabular}{c} 
1AW \\
\cline { 2 - 8 } \\
$(\mathrm{mpy})$
\end{tabular} & $\begin{array}{c}\text { 2AW } \\
\text { (mpy) }\end{array}$ & $\begin{array}{c}\text { 3AW } \\
(\mathrm{mpy})\end{array}$ & $\begin{array}{c}\text { 4AW } \\
(\mathrm{mpy})\end{array}$ & $\begin{array}{c}\text { 5OR } \\
(\mathrm{mpy})\end{array}$ & $\begin{array}{c}\text { 6OR } \\
(\mathrm{mpy})\end{array}$ & $\begin{array}{c}\text { COR } \\
(\mathrm{mpy})\end{array}$ \\
\hline 5 & 10.51 & 16.57 & 10.25 & 8.30 & 5.68 & 5.66 & 5.34 \\
\hline 10 & 9.56 & 9.65 & 9.62 & 5.66 & 5.45 & 5.53 & 5.40 \\
\hline 15 & 8.79 & 9.06 & 9.46 & 5.95 & 5.33 & 5.28 & 5.65 \\
\hline 20 & 8.77 & 8.66 & 7.54 & 5.72 & 5.44 & 5.76 & 4.95 \\
\hline 25 & 7.52 & 7.67 & 8.89 & 4.96 & 4.80 & 4.63 & 2.32 \\
\hline 30 & 7.51 & 7.59 & 6.71 & 4.85 & 4.85 & 5.65 & 4.34 \\
\hline 35 & 6.85 & 5.25 & 6.95 & 3.82 & 3.85 & 4.45 & 3.95 \\
\hline 40 & 6.52 & 6.90 & 5.98 & 3.71 & 3.64 & 3.76 & 3.82 \\
\hline 45 & 5.93 & 5.97 & 5.86 & 3.56 & 3.50 & 3.61 & 3.33 \\
\hline 50 & 5.59 & 5.01 & 4.82 & 3.50 & 3.46 & 3.88 & 3.67 \\
\hline \hline
\end{tabular}

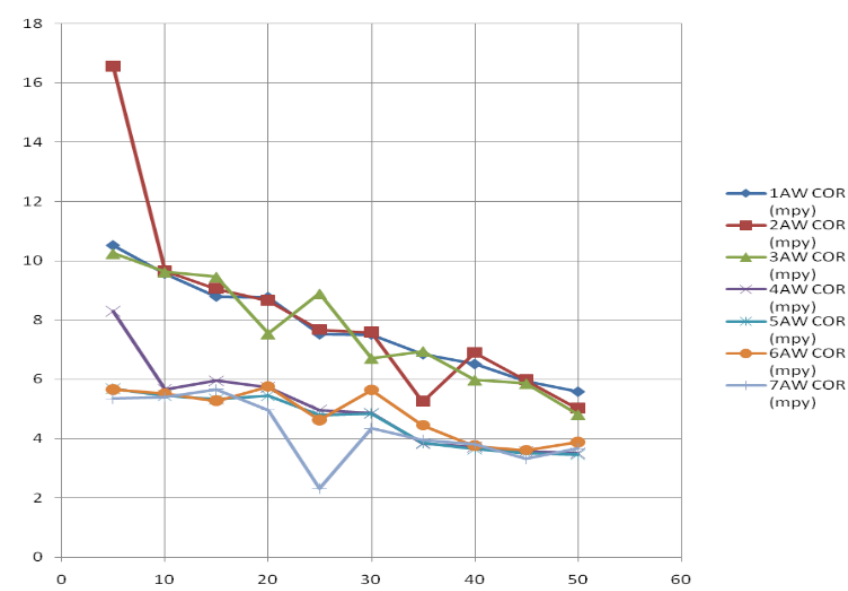

Fig. 4. Graphical representation of Table II (Immersion duration in nonoxidizing medium (HCL) versus corrosion rate (COR)

\section{Table III and Fig. 5}

From Table III and Fig. 5 below, samples 11A, 12A, 13A and $14 \mathrm{~A}$ have very sharp drop in corrosion rate (from very high to very low corrosion rate), as immersion duration increases in oxidizing medium of sulphoric acid $\left(\mathrm{H}_{2} \mathrm{SO}_{4}\right)$. Samples 8A, 9A, 10A have relatively initial lower corrosion rate than $11 \mathrm{~A}, 12 \mathrm{~A}, 13 \mathrm{~A}$ and $14 \mathrm{~A}$ in the oxidizing medium $\left(\mathrm{H}_{2} \mathrm{SO}_{4}\right)$, as immersion duration/soaking time increases, but fluctuates relatively at higher corrosion rate than $11 \mathrm{~A}, 12 \mathrm{~A}$, $13 \mathrm{~A}$ and $14 \mathrm{~A}$, as immersion duration/soaking time increases.

Careful study of the Table III and Fig. 5, showed that corrosion rate of samples $11 \mathrm{~A}, 12 \mathrm{~A}, 13 \mathrm{~A}$ and $14 \mathrm{~A}$, have lower corrosion rate than samples 8A, 9A, 10A, as immersion duration/soaking time increases. Sample 13A has the lowest corrosion rate among the samples at 30minutes of immersion duration. 
TABLE III: CORROSION RATE (COR) OF UNWELDED AISI 304 SAMPLES

(8A, 9A, 10A, 11A, 12A, 13A, 14A), SOAKED AT $750^{\circ} \mathrm{C}$ AT VARIABLE SOAKING TIME OF 30, 60, 180, 300, 400, 500 AND 600 MINUTES RESPECTIVELY AND IMMERSED IN OXIDIZING AGENT (H2SO4) AT VARIABLE

\begin{tabular}{|c|c|c|c|c|c|c|c|}
\hline \multicolumn{8}{|c|}{ IMMERSION DURATION } \\
\hline Immersion & $8 \mathrm{~A}$ & $9 \mathrm{~A}$ & $10 \mathrm{~A}$ & $11 \mathrm{~A}$ & $12 \mathrm{~A}$ & $13 \mathrm{~A}$ & $14 \mathrm{~A}$ \\
\hline $\begin{array}{c}\text { duration } \\
\text { (Minutes) }\end{array}$ & $\begin{array}{l}\text { COR } \\
\text { (mpy) }\end{array}$ & $\begin{array}{l}\text { COR } \\
\text { (mpy) }\end{array}$ & $\begin{array}{c}\text { COR } \\
\text { (mpy) }\end{array}$ & $\begin{array}{l}\text { COR } \\
\text { (mpy) }\end{array}$ & $\begin{array}{l}\text { COR } \\
\text { (mpy) }\end{array}$ & $\begin{array}{c}\text { COR } \\
\text { (mpy) }\end{array}$ & $\begin{array}{l}\text { COR } \\
\text { (mpy) }\end{array}$ \\
\hline 5 & 2.98 & 1.82 & 1.96 & 12.10 & 9.65 & 8.54 & 8.45 \\
\hline 10 & 3.45 & 2.65 & 3.02 & 8.18 & 8.54 & 7.34 & 7.62 \\
\hline 15 & 2.55 & 2.92 & 2.76 & 7.67 & 6.98 & 6.91 & 6.54 \\
\hline 20 & 2.45 & 2.67 & 3.08 & 1.48 & 1.45 & 1.21 & 4.32 \\
\hline 25 & 3.96 & 3.60 & 2.99 & 2.55 & 2.66 & 2.64 & 2.43 \\
\hline 30 & 3.65 & 2.45 & 2.65 & 1.42 & 1.68 & 1.46 & 1.28 \\
\hline 35 & 2.25 & 2.67 & 2.77 & 1.67 & 1.25 & 1.05 & 0.98 \\
\hline 40 & 2.69 & 2.53 & 2.80 & 1.22 & 0.89 & 0.95 & 0.86 \\
\hline 45 & 2.94 & 2.43 & 2.38 & 1.25 & 0.57 & 0.84 & 0.72 \\
\hline 50 & 2.75 & 2.69 & 2.34 & 0.99 & 0.29 & 2.99 & 3.05 \\
\hline
\end{tabular}

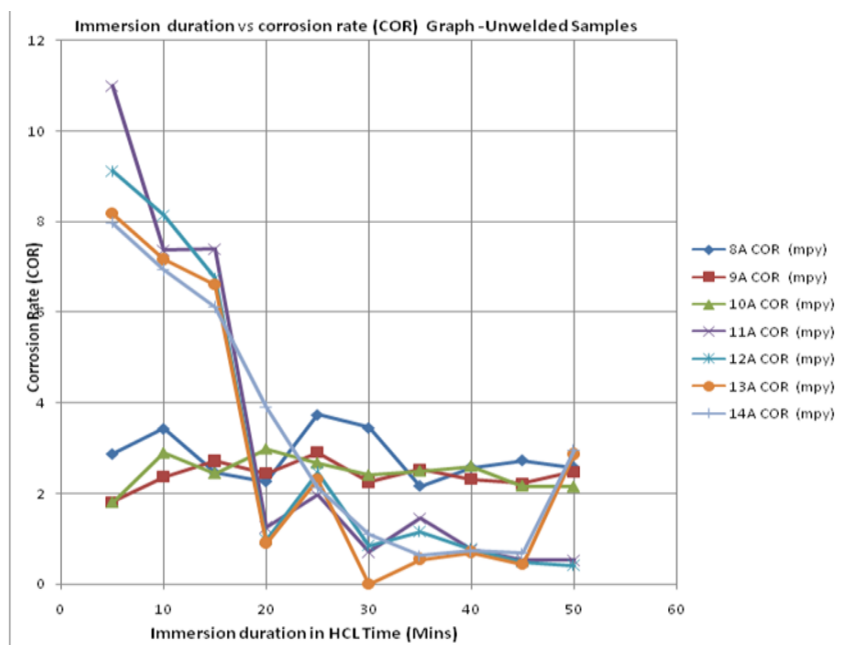

Fig. 5. Graphical relationship of immersion duration(minutes) in oxidizing medium $\left(\mathrm{H}_{2} \mathrm{SO}_{4}\right)$ versus corrosion rate (COR) for various samples in Table III

\section{Table IV and Fig. 6}

From Table IV and Fig. 6 below, samples 8AW has the highest corrosion rate at 5minutes of immersion duration, followed by samples 9AW. Sample 11AW has sharp decrease in corrosion rate between 5 and 10 minutes at immersion duration.

Careful observations showed that all the samples (8AW, 9AW, 10AW 11AW, 12AW, 13AW and 14AW), have corrosion rate averagely decreasing as immersion duration /soaking time increases. Samples 11AW, 12AW, 13AW, $14 \mathrm{AW}$, have lower corrosion rates than samples $8 \mathrm{AW}$, $9 \mathrm{AW}, 10 \mathrm{AW}$, as immersion duration /soaking time increases, at constant soaking temperature.

TABLE IV: CORROSION RATE (COR) OF UNWELDED AISI 304 SAMPLES (8AW, 9AW, 10AW, 11AW, 12AW, 13AW, 14AW), SOAKED AT $750^{\circ} \mathrm{C}$ AT VARIABLE SOAKING TIME OF 30, 60, 180, 300, 400, 500 AND 600 MINUTES RESPECTIVELY AND IMMERSED IN OXIDIZING AGENT $\left(\mathrm{H}_{2} \mathrm{SO}_{4}\right)$ AT VARIABLE

\begin{tabular}{|c|c|c|c|c|c|c|c|}
\hline \multirow{3}{*}{$\begin{array}{l}\text { Immersion } \\
\text { duration } \\
\text { (Minutes) }\end{array}$} & \multicolumn{6}{|c|}{ IMMERSION TIME } & \multirow[b]{2}{*}{ 14AW } \\
\hline & $8 \mathrm{AWW}$ & 9AW & 10AW & $111 \mathrm{AW}$ & 12AW & 13AW & \\
\hline & $\begin{array}{l}\text { COR } \\
\text { (mpy) }\end{array}$ & $\begin{array}{c}\text { COR } \\
\text { (mpy) }\end{array}$ & $\begin{array}{c}\text { COR } \\
(\mathrm{mpy})\end{array}$ & $\begin{array}{c}\text { COR } \\
\text { (mpy) }\end{array}$ & $\begin{array}{l}\text { COR } \\
\text { (mpy) }\end{array}$ & $\begin{array}{c}\text { COR } \\
\text { (mpy) }\end{array}$ & $\begin{array}{c}\text { COR } \\
\text { (mpy) }\end{array}$ \\
\hline 5 & 9.56 & 8.47 & 7.85 & 7.95 & 5.65 & 4.54 & 5.65 \\
\hline 10 & 6.85 & 7.57 & 6.92 & 3.45 & 3.54 & 3.85 & 4.20 \\
\hline 15 & 6.45 & 6.54 & 6.05 & 3.32 & 3.60 & 3.55 & 5.02 \\
\hline 20 & 6.25 & 5.93 & 5.54 & 3.18 & 3.57 & 3.95 & 4.16 \\
\hline 25 & 5.55 & 5.67 & 4.99 & 2.92 & 2.79 & 3.66 & 3.03 \\
\hline 30 & 5.26 & 5.56 & 4.65 & 2.75 & 4.62 & 3.45 & 3.28 \\
\hline 35 & 4.38 & 4.45 & 3.99 & 2.66 & 2.92 & 2.99 & 3.24 \\
\hline 40 & 4.90 & 3.99 & 3.65 & 2.60 & 2.60 & 2.85 & 2.99 \\
\hline 45 & 4.63 & 3.25 & 3.40 & 2.40 & 2.70 & 2.86 & 3.61 \\
\hline 50 & 3.57 & 3.14 & 4.02 & 2.32 & 2.43 & 2.60 & 3.05 \\
\hline
\end{tabular}

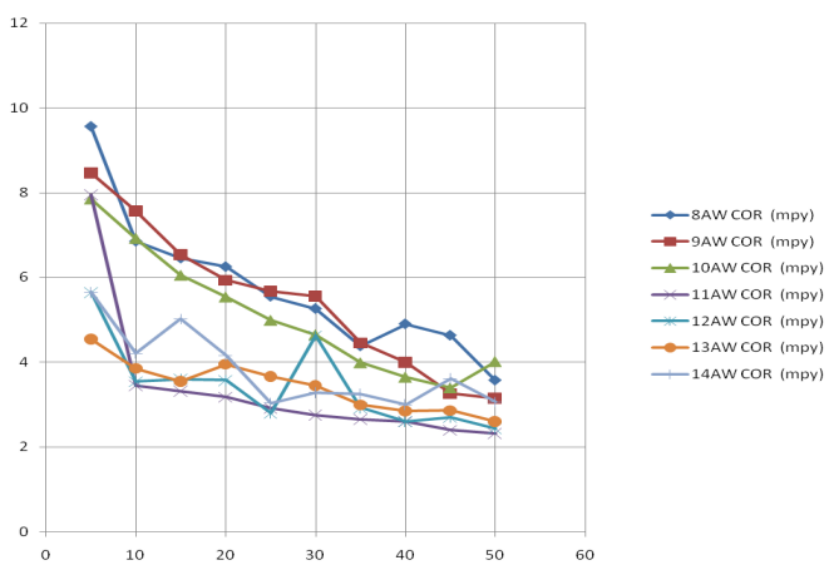

Fig. 6. Graphical relationship of immersion duration in oxidizing agent $\left(\mathrm{H}_{2} \mathrm{SO}_{4}\right)$ versus corrosion rate (COR) for various samples in Table IV

\section{E. Table V and Fig. 7}

Careful study of Table V and Fig. 7 below, showed that average corrosion rate of the unwelded samples $1 \mathrm{~A}-7 \mathrm{~A}$ and welded samples $1 \mathrm{AW}-7 \mathrm{AW}$, decreases with increase in immersion duration/soaking time in non-oxidizing agent of HCL; but the rate of decrease is higher in the unwelded samples than that of the welded samples, as immersion duration and soaking time increases.

TABLE V: AVERAGE CORROSION RATE OF AISI 304 SAMPLES OF UNWELDED (1A, 2A, 3A, 4A, 5A, 6A, 7A) AND WELDED (1AW, 2AW, 3AW, 4AW, 5AW, 6AW, 7AW), SOAKED AT $750^{\circ} \mathrm{C}$ AT VARIABLE SOAKING TIME OF 30, 60, 180, 300, 400, 500 AND 600 MINUTES RESPECTIVELY AND IMMERSED IN NON-OXIDIZING AGENT (HCL) AT VARIABLE IMMERSION TIME

\begin{tabular}{cccc}
\hline \hline \multicolumn{2}{c}{ Unwelded 1A-7A } & \multicolumn{2}{c}{ Welded 1AW-7AW } \\
\hline $\begin{array}{c}\text { Immersion duration } \\
\text { (Minutes) }\end{array}$ & $\begin{array}{c}\text { COR (mpy) } \\
\text { (Average) }\end{array}$ & $\begin{array}{c}\text { Immersion duration } \\
\text { in HCL Time (Mins) }\end{array}$ & $\begin{array}{c}\text { COR (mpy) } \\
\text { (Average) }\end{array}$ \\
\hline 5 & 6.93 & 5 & 8.90 \\
\hline 10 & 5.34 & 10 & 7.27 \\
\hline 15 & 3.40 & 15 & 5.19 \\
\hline 20 & 3.50 & 20 & 6.69 \\
\hline 25 & 3.40 & 25 & 5.83 \\
\hline 30 & 3.40 & 30 & 5.93 \\
\hline 35 & 3.08 & 35 & 5.02 \\
\hline 40 & 2.74 & 40 & 5.02 \\
\hline 45 & 2.95 & 45 & 4.54 \\
\hline 50 & 2.68 & 50 & \\
\hline \hline
\end{tabular}

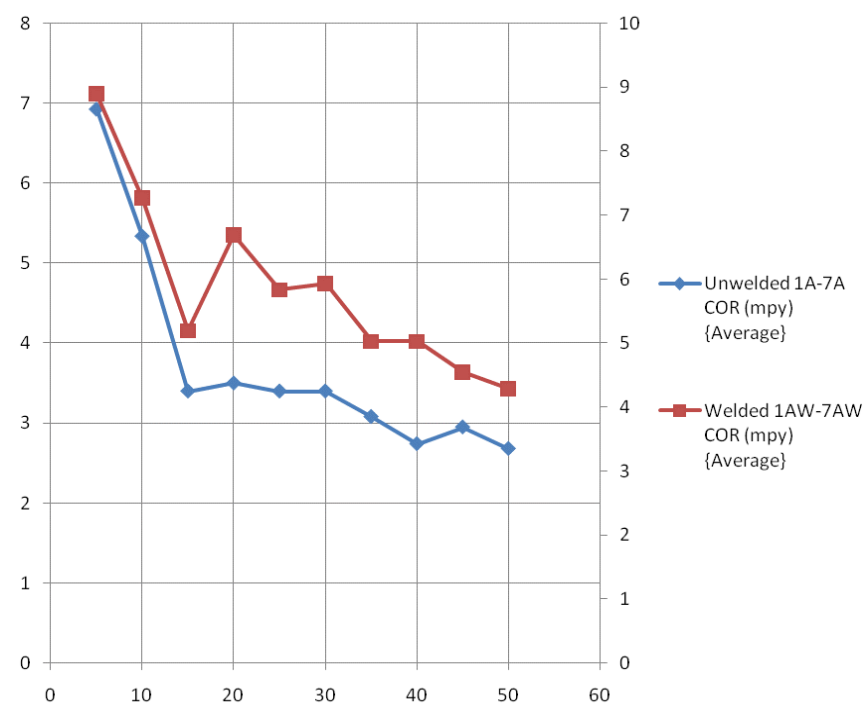

Fig. 7 Graphical relationship of immersion duration in non-oxidizing medium (HCL) versus average corrosion rate (COR) for various samples of welded and unwelded as shown in Table $\mathrm{V}$ 


\section{F. Table VI and Fig. 8}

Careful study of Table VI and Fig. 8 below showed that average corrosion rate of the unwelded samples 8A-14A and welded samples $8 \mathrm{AW}-14 \mathrm{AW}$ decreases with increase in immersion duration/soaking time in oxidizing agent $\left(\mathrm{H}_{2} \mathrm{SO}_{4}\right)$. However, surprisingly between 5-15 minutes of immersion duration, the rate of corrosion rate decrease is lower in welded samples; but reverses to higher rate relative to $8 \mathrm{~A}-14 \mathrm{~A}$ between 15-50 minutes of immersion duration in the oxidizing medium $\left(\mathrm{H}_{2} \mathrm{SO}_{4}\right)$.

TABLE VI: AVERAGE CORROSION RATE OF AISI 304 SAMPLES OF UNWELDED (8A, 9A, 10A, 11A, 12A, 13A, 14A) AND WELDED (8AW, 9AW, $10 \mathrm{AW}, 11 \mathrm{AW}, 12 \mathrm{AW}, 13 \mathrm{AW}, 14 \mathrm{AW})$, SOAKED AT $750^{\circ} \mathrm{C}$ AT VARIABLE SOAKING TIME OF 30, 60, 180, 300, 400, 500 AND 600 MINUTES RESPECTIVELY AND IMMERSED IN OXIDIZING AGENT $\left(\mathrm{H}_{2} \mathrm{SO}_{4}\right)$ AT VARIABLE IMMERSION TIME

\begin{tabular}{|c|c|c|c|}
\hline \multicolumn{2}{|c|}{ " Unwelded (8A-14A) } & \multicolumn{2}{|c|}{ "Welded (8AW-14AW) } \\
\hline $\begin{array}{c}\text { Immersion } \\
\text { (Soaking) duration } \\
\text { in }\left(\mathrm{H}_{2} \mathrm{SO}_{4}\right) \text { Time } \\
(\mathrm{Mins})\end{array}$ & $\begin{array}{c}\text { COR } \\
\text { (mpy) } \\
\text { (Average) }\end{array}$ & $\begin{array}{c}\text { Immersion(Soaking) } \\
\text { duration in }\left(\mathrm{H}_{2} \mathrm{SO}_{4}\right) \\
\text { Time (Mins) }\end{array}$ & $\begin{array}{c}\text { COR } \\
\text { (mpy) } \\
\text { (Average) }\end{array}$ \\
\hline 5 & 6.50 & 5 & 7.10 \\
\hline 10 & 5.83 & 10 & 5.20 \\
\hline 15 & 5.19 & 15 & 4.93 \\
\hline 20 & 2.38 & 20 & 4.65 \\
\hline 25 & 2.98 & 25 & 4.09 \\
\hline 30 & 2.08 & 30 & 4.22 \\
\hline 35 & 1.81 & 35 & 3.52 \\
\hline 40 & 1.72 & 40 & 3.37 \\
\hline 45 & 1.59 & 45 & 3.26 \\
\hline 50 & 2.16 & 50 & 3.02 \\
\hline
\end{tabular}

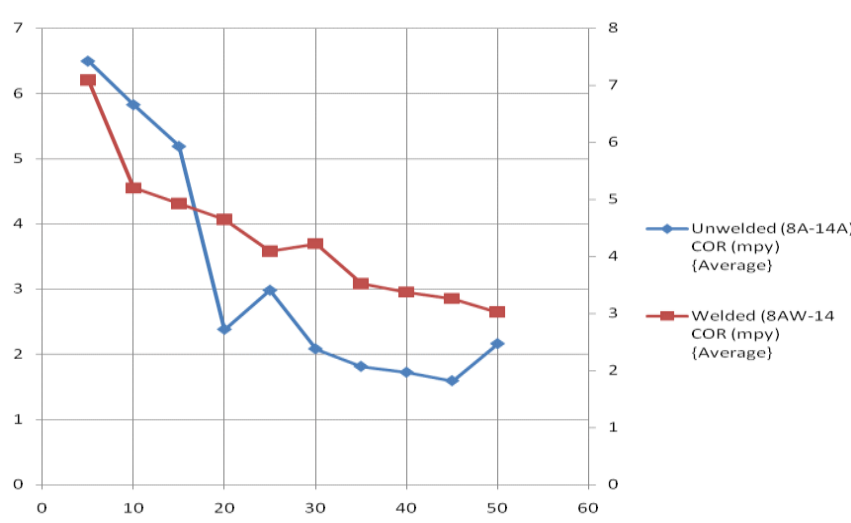

Fig. 8. Graphical relationship of immersion time in oxidizing agent $\left(\mathrm{H}_{2} \mathrm{SO}_{4}\right)$ versus average corrosion rate (COR) for various samples of welded and unwelded as shown in Table VI

\section{CONCLUSIONS}

Based on the above experimental results/analysis, the following may be concluded:

1. The corrosion rate of unwelded and welded samples of AISI 304 in non-oxidizing environment of HCL decreases as immersion duration/soaking time increases at constant soaking temperature.

2. Corrosion rate decrease in unwelded samples of AISI 304 is greater than that of the welded samples as immersion duration and soaking time increases in oxidizing agent of HCL.

3. Average corrosion rate of the unwelded samples and welded samples of AISI 304 decreases with increase in immersion duration/soaking time in oxidizing medium $\left(\mathrm{H}_{2} \mathrm{SO}_{4}\right)$.
4. The unequilibrium heat cycles during welding, which resulted in complex reactions/phase transformation, could have led to different degree of sensitization in the welded and unwelded steel samples.

5. The degree of sensitization in the steel weldment and the unwelded counterpart are different in both oxidizing agent $\left(\mathrm{H}_{2} \mathrm{SO}_{4}\right)$ and non-oxidizing agent (HCL).

6. Each experimental sample reacted differently in the oxidizing and non-oxidizing media and hence its corrosive properties were impacted differently.

7. The microstructural differences of the welded and the unwelded counterpart significantly affected their reaction in oxidizing and non-oxidizing media which led to differences in the corrosive impacts, under the same environment/condition.

\section{REFERENCES}

[1] Silas Ezedinma Agbokwor, Simeon Ikechukwu Neife: Investigation of the Effects of Soaking Time on the Properties of Stainless Steel: American Journal of Mechanical and Materials Engineering.Vol.3, No.3, 2019, pp.47-52. doi: 10.11648/j.ajmme.20190303.11

[2] Pierre R. Roberge: Corrosion Basics: An Introduction, Second Ed. (Houston, TX: NACE International, 2006), pp. 21-22.

[3] National Corrosion Service (NCS) Publication UK. Guides to good practice in corrosion control. (www.npl.co.uk), 2000.

[4] Rondelli, G.; Vicentini, B. Susceptibility of highly alloyed austenitic stainless steels to caustic stress corrosion cracking. Mater. Corros. 2002, 53, 813-819.

[5] Rondelli, G.; Vicentini, B.; Sivieri, E. Stress corrosion cracking of stainless steels in high temperature caustic solutions. Corrosion Science 1997, 39, 1037-1049.

[6] Parnian, N. Failure analysis of austenitic stainless steel tubes in a gas fired steam heater. Mater. Des. 2012, 36, 788-795.

[7] Betova, I.; Bojinov, M.; Hyökyvirta, O.; Saario, T. Effect of sulphide on the corrosion behaviour of AISI $316 \mathrm{~L}$ stainless steel and its constituent elements in simulated kraft digester conditions. Corrosion Science. 2010, 52, 1499-1507.

[8] Chasse, K.; Raji, S.; Singh, P. Effect of chloride ions on corrosion and stress corrosion cracking of duplex stainless steels in hot alkalinesulfide solutions. Corrosion 2012, 68, 932-949.

[9] Kumar, S.; Shahi, A.S. On the influence of welding stainless steel on microstructural development and mechanical performance. Mater. Manuf. Process. 2014, 29, 894-902.

[10] Frankel, G., et al. Localized corrosion: general discussion; Faraday Discussions. 2015 180(0): P.381-414.

[11] Zheng S, Shibata T, Haruna T: Corrosion Science Journal, 2005, 47, 1049-1061.

[12] Aydogbu GH, Aydinnol MK: Corrosion Science Journal, 2006, 48, 3565-3583.

[13] Seifedine, K (2008): European Journal of Scientific Research, ISSN 1450-216X Vol. 22 No.4, 2008, 508-516.

[14] Pitting Corrosion," NACE International, http://www.nace.org/PittingCorrosion (September 28, 2015).

[15] F. Haraszti, T. Kovács: Plastic deformation effect of the corrosion resistance in case of austenitic stainless steel, IOP Conference Series: Materials Science and Engineering 175: Paper 012048.4 (2017).

[16] G.H. Koch, et al., "Corrosion Costs and Preventive Strategies in the United States," Federal Highway Administration, FHWA-RD-01-156, March 2002.

[17] Sindou Kou (2003). Welding Metallurgy. 2nd Ed. A John Wiley and Sons, INC. Publication. New Jersey.

[18] F. Haraszti: The bases of corrosion investigation EME press, Müszaki Tudományos Füzetek 21, Cluj Napoca (2016) pp. 185-188.

[19] F. Haraszti: Corrosion investigation of steel samples EME press, Müszaki Tudományos Füzetek 21, Cluj Napoca (2016) pp.189-192.

[20] M. Dománkova, et al: The microstructure evolution and its effect on corrosion properties of $18 \mathrm{Cr}-12 \mathrm{Ni}-2,5 \mathrm{Mo}$ Steel, annealed at 500 $900^{\circ} \mathrm{C}$, Acta Polytechnica Hungarica, 11(3(2014) pp.125-137

[21] Newman, R. C. 2001 W. R. Whitney award lecture: understanding the corrosion of stainless steel; Corrosion 2001. 57(12): P. 1030-1041 
[22] NACE international conference \& EXPO; CORROSION 2016 PAPER NO.7083. The role of local chemistry changes in the repassivation of localized corrosion.

[23] NACE international conference \& EXPO; CORROSION 2016 PAPER NO.7083: The role of local chemistry changes in the repassivation of localized corrosion.

[24] Li SL, Zhang HL, Wang YL, Li SX, Zheng K, Xue F, Wang XT. Annealing induced recovery of long-term thermal aging embritlement in a duplex stainless steel. Material Science Engineering A 2013 564:85-91.

[25] Mateo A, Palomino JL, Salan N, Llanes L, Anglada M. Mechanical evaluation of a reversion heat treatment for a duplex stainless steel thermally embrittled. In: ECF 11 - mechanisms and mechanics of damage and failure, vol. 1, 1996.

[26] T. Kovács, L. Kuzsella: High Energy Rate Forming Induced Phase Transition in austenitic steel; Journal of Physics Conference-Series 790: Paper 012039. 5 (2017) 